\title{
Camoufl-Ages: Body Assemblages at the Time of the Apocalypse
}

\author{
Giuseppina Botta \\ University of Salerno \\ giuseppinabotta@gmail.com
}

\begin{abstract}
Performance deals with embodiment, presence, agency and event. It is related to representation and consists in the display of an action with the presence of observers (Schechner). In Margaret Atwood's Oryx and Crake (2003) and The Year of the Flood (2009) performance is connected with the protagonists' struggle for survival, which proves particularly complex because of the complete subversion of the environmental conditions, in a post-apocalyptic future dominated by the harsh consequences of an unscrupulous exploitation of genetic engineering. Scholars have discussed the theme of survival in Atwood's novels with regard to power politics and victimhood. In my essay through a series of ecocritical studies (Warren, Otto, Castricano, Sehadri), I will explore the distorted relationship between human culture and environment provoked by the excessive manipulation of the living matter, whether human or animal, which alters the perception of the self and of being in general. My focus will be on the notions of mimicry and camouflage.
\end{abstract}

A preoccupation with one's survival is necessarily also a preoccupation with the obstacles to that survival (Margaret Atwood, Survival, 1972) 


\section{Introduction}

Embodiment, presence, agency and event are the key words in performance. As Richard Schechner notices, with reference to everyday life, "to perform" means "to show off, to go to extremes, to underline an action for those who are watching" (Schechner, 2013: 28). In Margaret Atwood's Oryx and Crake (2003) and The Year of the Flood ${ }^{1}$ (2009) performance is connected with the protagonists' struggle for survival, which proves particularly complex because of the complete subversion of the environmental conditions, in a post-apocalyptical future dominated by the harsh consequences of an unscrupulous exploitation of genetic engineering. As the epigraph to this paper suggests, there are various reasons behind "the obstacles to that survival": genetic manipulations in the animal realm, the almost total decimation of mankind due to a pandemic event, pollution and solar radiation anomalies. In another context Atwood stresses that each character "does more than survive, but is mutilated in the process" (Atwood, 1972: 20); in other words, Jimmy (the protagonist of Oryx and Crake) and Toby and Ren (main characters of The Year of the Flood) employ diverse survival strategies, such as refuge in the memories of the past, agricultural activities (in Toby's case) and camouflage. However, on their way to salvation they face several stages of self-alienation and identity loss.

Survival is a significant theme in Atwood's oeuvre; in Survival: A Thematic Guide to Canadian Literature (1972), the author identifies it as the central metaphor for Canadian literature. Far from being a mere act of living through difficult times, survival constitutes an entire forma mentis which pervades both the people and the literature of the nation. Atwood explores the typologies of landscape present in Canadian literature and people's attitudes towards the natural world. According to the author the physical landscape is a representation of an interior state, since landscapes are "maps of a state of mind" (Atwood, 1972: 49). Nature is thus personified, as the geographic features of a country have a strong impact on the writers' mind. It is not by chance, in fact, that Atwood uses a capital "N" when writing about it. Thus, more than a scenery or a physical setting, Nature becomes an entity which both strikes and haunts the creative mind. Atwood points out that the early Canadian writers' perception of Nature was still influenced by the Wordsworthian vision, according to which man and nature are different but inseparable parts of a whole universe, a total scheme created by God, or rather by a mighty Power. Nature, far from being a decorative background or simply the mirror of a particular mood, was endowed with a spirit and a life of its own, present not only in plants and animals, but in inanimate objects as well. It was then through a fusion with nature, and through a quiet contemplation of its beauty, that man could rediscover the image of God and become aware of his own inner life, since Man and Nature fitted together perfectly as parts of one Mighty Mind. Nature, in fact, was a source of comfort to man, the only great principle from which, by penetrating into its divine essence, man could learn virtue and wisdom.

This vision clashes with the sense of exclusion produced by Canadian Nature, perceived as mute, hostile or impalpable. Atwood identifies some recurrent themes such as death by Nature, Nature as a monster and Nature as a dangerous woman or ice 
goddess. She defines death by Nature as "something in the natural world [which] murders the individual" (Atwood, 1972: 54). Nature's murdering intention has two variations: the victim, in fact, may die by drowning or freezing. The former modality is mainly peculiar to poetry, the latter to prose. Death by Nature, however, sometimes turns into Death by Bushing, "in which a character isolated in Nature goes crazy" (Atwood, 1972: 55). To the European mind-set, nature is supposed to be a source of inspiration and beauty, virtue and wisdom, but the harsh territory and climate ascribe to it negative connotations. Nature is felt to be dangerous, and its lack of order becomes unacceptable; thus the writer, who previously found it familiar (heimlich), now perceives it as foreign and uncomfortably strange (unheimlich): "Nature is hostile and is out to get me" can mean also "I feel small, helpless and victimized. I seem to have little power over my own destiny" (Atwood, 1972: 62). Since Nature is familiar and strange at the same time, the subject experiences a cognitive dissonance due to the paradox of being both attracted to and repulsed by it. This, however, does not presume a dialectic structure of Nature; it is not, in fact, organized according to couples of opposite forces, consisting of a negative and a positive pole: "[Nature] exists as itself, I suspect, but not as a collection of separate and inert objects; rather it exists as a living process which includes opposites: life and death, 'gentleness' and 'hostility"' (Atwood, 1972: 63).

Later on in Atwood's literary production survival is still a central theme. With regard to her novels, for example, Surfacing (1972) focuses on the survival strategies of the unnamed female protagonist, who struggles with her sorrowful memories of the past and her father's mysterious disappearance. In this novel "to survive" means to get over traumatic experiences (such as an abortion), but also to endure the spartan living conditions in the forest, which the protagonist experiences during her isolation from civilization. In The Handmaid's Tale (1985) survival deals with adaptation. In the Republic of Gilead, ruled by a totalitarian regime, women are on the lowest level of the social ladder. Most of them, including Offred, the protagonist, become concubines, or handmaids, of the regime troop commanders. They are like sexual slaves, who are obliged to copulate with their commander in order to procreate in a polluted environment which has caused mankind sterility.

Scholars have extensively discussed the theme of survival in Atwood's oeuvre. Let me give just a few examples: David Staines focuses on the concept of "victimization" (Staines, 2006: 18); Pilar Somacarrera, instead, points out the possibility that Atwood has "to deal with all kinds of power relationships" (Somacarrera, 2006: 45); and Heidi Slettedahl Macpherson notices the "abdicating responsibility" presumed by the position of victim (Macpherson, 2010: 104). My analysis does not focus on power politics nor on the identification of potential victimhood. Through a series of ecocritical studies (Warren,1997; Plumwood, 1993; Adams, 2003; Otto, 2012; Castricano, 2008; Sehadri, 2012; De Fontenay, 2008/2012), I will explore the distorted relationship between human culture and environment provoked by the excessive manipulation of the living matter, whether human or animal, which alters the perception of the self and of being in general. 
Schechner makes a distinction between being, doing and showing doing: "“Being' is existence itself. 'Doing' is the activity of all that exists [...]. 'Showing doing' is performing: pointing to, underlining, and displaying doing" (Schechner, 2013: 28). In Atwood's latest novels, the protagonists are completely alienated from a world which has lost all patterns of recognisability. As a consequence, they live in a shifting condition: on the one hand they encounter the impossibility of being, the awareness of the impracticability of their existence as it used to be before the world apocalypse; on the other hand they seek to react through performative strategies which lead to the reconstruction of their selves. In fact, as Marvin Carlson highlights, performance deals with "re-doing" (Carlson, 1996: 195), or in Schechner's terms with "restored behaviours" (Schechner, 2013: 28) or "twice-behaved behaviours" (Schechner, 2013: 28). According to Carlson, performativity constitutes the "embodiment of the tension between a given form or content from the past and the inevitable adjustments of an ever-changing present" (Carlson, 1996: 195). The protagonists' adjustments are made on the terrain of the body, a tangible matter, subject to diverse manipulations, which allows them to play a role in particular situations.

Erving Goffman defines performance as "all the activity of an individual which occurs during a period marked by his continuous presence before a particular set of observers and which has some influence on the observers" (Goffman, 1969: 32). Following this pattern, my analysis considers the concepts of mimicry and camouflage in relation to corporeity through the ecocritical perspective, with particular emphasis on the problematic association between female and animal bodies. Mimicry and camouflage presume the disappearance of a subject (Irigaray, 1985), who hides him/herself from the others. Invisibility can be attained by means of two different strategies: through an assimilation to the environment in order to become blended and indistinct, or through the assumption of a different shape so as to pass as someone else.

Both in Oryx and Crake and in The Year of the Flood the protagonists wear disguises to interact with their interlocutors or undergo physical manipulations and transformations in order to escape from perils. The success of their performances relies on the credibility they gain through their re-created selves, as Goffman points out when speaking about the perfect performance: "To be a given kind of person, then, is not merely to possess the required attributes, but also to sustain the standards of conduct and appearance that one's social grouping attaches thereto" (Goffman, 1969: 81). The ability to act, speak, behave 'as if' they were someone else enacts and creates a kaleidoscopic set of performances through which they will also define their social role: "When an individual or performer plays the same part to the same audience on different occasions, a social relationship is likely to arise" (Goffman, 1969: 16).

\section{Reaching towards new identities}

Camouflage deals with disguise, misleading, concealment; it consists of any device or means through which one can conceal one's own nature, in order to deceive an 
adversary. This is certainly the case of Toby, one of the protagonists of The Year of the Flood, who moves through mimicry and camouflage in order to remain "vigilant in her will to survive" (Jennings, 2010: 16). After a very harsh life of family tragedies and poverty, and after the sometimes dangerous commitment to survival, Toby finds a refuge among the God's Gardeners community, a pseudo-religious sect devoted to ecosustainability. Once among them, Toby learns how to recycle fabrics, how to cultivate vegetables without chemical pesticides and how to produce drugs from natural substances. In this green microcosm her dignity as both woman and human being is restored. As Anca Farca points out, in The Year of the Flood "women are neither leaders nor decision makers, as the futuristic society envisioned by the author is controlled by big corporations and male scientists and policed by corporate security forces" (Anca Farca, 2010: 18). Before joining the Gardeners, as an orphan, a person without a job, Toby was set at the very bottom of the social ladder, and was terrified by the possibility of "being farmed out for sex" (YF: 36), as all female debtors are. In order to survive, she renounces her personal identity and cancels her social status:

She's burned her identity and didn't have the cash to buy a new one [...] so she couldn't get a legitimate job [...] But if you sank deep down - down where names disappeared and no histories were true - the CorpSeCorps wouldn't bother with you (YF:36).

Thus, the processes of mimicry and camouflage she goes through presuppose a concurrent self-annihilation.

Both mimicry and camouflage imply the ability to deceive a predator by hiding from it through assimilation with the natural surroundings. Mimicry, as Homi Bhabha points out, is "a complex strategy of reform, regulation and discipline" (Bhabha, 1994: 86). Luce Irigaray discusses this concept from a gender perspective in This Sex That is not One (1985). She views mimicry with regard to the exclusion of the female element from the sphere of patriarchal power. Mimicry constitutes a device through which women "protect themselves against (re)assimilation and destruction by the masculine economy" (Whitford, 1991:72). As Irigaray puts it, the function of mimicry is "to unveil", "to make "visible' [...] what was supposed to remain invisible" (Irigaray, 1985: 76) through the concealment of certain features which could make the woman vulnerable.

On a first level, Toby interrupts the balance between self identity and social identity and disappears "deep down" (YF: 36), in the limbo of the derelicts, of the social outcasts: she rents a room in a peripheral area, and her neighbours are six illegal Thai immigrants who share with her the need for anonymity, due to the CorpSeCorps's repressive measures: "They'd resorted to the method used by farmers who found a diseased cow in the herd: shoot, shovel and shut up" $(Y F: 37)$. In this dimension of invisibility, Toby experiments with various means to survival, such as selling her hair and her ova: "The hair market hadn't yet been decimated by the Mo'Hair sheep breeders [...] so there were still scalpers who'd buy from anyone, no questions asked" (YF: 38). The concept of the self is profoundly and indissolubly connected with corporeity, because the body is a primeval source of subjectivity. Every manipulation 
Toby inflicts on her body contributes to a fragmentation of her identity, both as a woman and as a human being. The principle of wholeness is subverted in favour of a cultural belief of the futuristic society she lives in, which considers the body as a malleable, manipulatable material, released from its own biological dynamics and mechanisms. In Toby's case, this is evident in the sale of her ova to the black market: "Young women could get top dollar for donating their eggs to couples who hadn't been able to pay the required bribe or else were so truly unsuitable that no official would sell them a parenthood license anyway" ( $Y F: 38)$. Nevertheless, this activity will not be lucrative for long, because "the second time the extraction needle had been infected [...] so she could never donate any more eggs, or - incidentally- have any children herself" (YF: 38).

\section{Sales in the genetic supermarket}

The concept of reproduction, both human and animal, is a fundamental theme in Oryx and Crake and The Year of the Flood. In Oryx and Crake the animal realm is partly rearranged through the creation of new hybrid species which elude human control and, instead of being mere experimental tools, become the "hunters" in a wild and unhomely landscape. One of the most infesting and dangerous creatures is the pigoon, a transgenic pig, the product of the studies and experiments of a genographers group which included Jimmy's father:

Pigoon was only a nickname: the official name was sus multiorganifer. [...] The goal of the pigoon project was to grow an assortment of foolproof human- tissue organs in a transgenic knockout pig host - organs that would transplant smoothly and avoid rejection $[\ldots] .(O C: 25)$

Furthermore the ability of such genographers, who could "manipulate hereditary material through artificial selection, hybridization, or mutagenesis" (Anker and Nelkin, 2003: 66), developed into a creative activity, with some unpredictable inconveniencies:

[...] create-an-animal was so much fun, said the guys doing it; it made you feel like God. A number of experiments were destroyed because they were too dangerous to have around - who needed a cane toad with a prehensile tail like a chameleon's that might climb in through the bathroom window and blind you while you were brushing your teeth? $(O C: 57)$

This new genetically modified bestiary also includes the wolfog (a hybrid of wolf and dog), the bobkitten (half way between the lynx and the cat) and the more 'domestic' rakunk, a pet created by combining the genetic material of a racoon and a skunk:

It was black and white - black mask, white stripe down its back, black and white rings around its fluffy tail. [...] 'No smell to it, not like a skunk', said Jimmy's father. 'It's a clean animal, with a nice disposition. Placid. Racoons never made good pets once they 
were grown up, they got crabby, they'd tear your house to pieces. This thing is supposed to be calmer. (OC: 58$)$

The word 'thing' which Jimmy's father uses to refer to the little creature, exemplifies the objectification of these new biological chimeras which, as animals, are already confined to the non-human dimension, but which become, also, non-living things. Jimmy's mother, a former scientist herself, condemns such unscrupulous exploitation of living matter, and blames her husband for the alteration of the natural order:

That's all we need..[...] more people with the brains of pigs. Don't we have enough of those already? [...] There's research and there's research. What you're doing - this pig brain thing. You're interfering with the building blocks of life. It's immoral. It's...sacrilegious. (OC: 63-64)

The creation of a life becomes a laboratory phenomenon which excludes any coupling ritual, as Carol Collier highlights: "Science and technology have [...] allowed us to separate [...] reproduction from the sexual act" (Collier, 2010: 34). This becomes more evident in the creation of Crake's offspring: the Crakers. "They were naked, [...] there was no self-consciousness, none at all. At first he couldn't believe them, they were so beautiful. Black, yellow, white, brown, all available skin colours. Each individual was exquisite" (OC: 355). Crake embodies "the desire for power at any price" (Spivack, 1992:13); he uses "science to alter life and influence human evolution" (Peters, 2002: 12), affecting profoundly and irreparably the destiny of mankind. In a godlike attitude, he becomes the sole parent of a whole progeny, which he names after his nickname (his first name being Glenn). As a matter of fact, 'Craker' stands for 'of Crake'. Manipulating human DNA and crossbreeding it with animals, he creates a human transgenic species, immune from any illness, perfect in its beauty and free of aggressive behaviour:

It was the result of a logical chain of progression, said Crake that evening, [...] Once the proteonome had been fully analyzed and interspecies gene and part-gene splicing were thoroughly underway, the Paradice Project or something like it had been only a matter of time. $(O C: 356)$

In this process, the female presence is completely neglected, and Crake never reveals the origin of the embryos: "At first," said Crake, "we had to alter ordinary human embryos, which we got from-never mind where we got them" (OC: 356). In the realm of reproductive technologies, the concept of woman becomes "elusive" (Haraway, 1991: 155) and the female element turns, in the words of Carol J. Adams, into an 'absent referent'. The notion "refers to a paradoxical use of language in which something is both present and absent" (Cavalieri, 2008: 101). Women are present as donors of ova, embryos or gametes, which constitute "the raw materials for making children" (Collier, 2010: 33); at the same time, they are absent, because they are considered mere generators of life, and once the gametes are extracted from the body, the process of reproduction continues somewhere else. As in Toby's case, the necessary 
anonymity of the donor emphasizes the invisibility of the female contribution. Val Plumwood highlights the instrumental function of both nature and female body:

If in the rationalistic paradigm, the male body is made rational by being made the instrument of a rationality which transforms nature, the female body is made part of culture by being subject to the control of others taken to represent rationality: medical and other experts, abortion tribunals and the like. As dualised nature, conceived as inert, passive, non-subjects, women have offered a fertile field for such control and manipulation. (Plumwood,1993: 38)

Crake finds and pays occasional mothers who are functional for his purposes; in the case of his children, for example, he provides a female figure in order to educate them in botany and zoology. This is the role of Oryx, a young girl, with blurry Cambodian features, whom he buys on a pornographic website. Despite his love for her, Crake defines her role in economic terms: "I have to say she's a devoted employee" (OC: $365)$.

Unexpectedly and in a less obvious manner, the processes of mimicry and camouflage involve also Crake's genetic deeds. Mimicry is "the action or skill of imitating someone or something" (Oxford English Dictionary, 2013), and Oryx enacts a mimetic strategy when, naked, she enters Paradice, the setting in which Crakers are raised, in order to instruct them. When Jimmy asks the reason for her nudity, Crake answers: "They've never seen clothes. Clothes would only confuse them" (OC: 363), and informs him about some other camouflage stratagems:

Then she'd spray herself with a citrus-derived chemical compound to disguise her human pheromones. When she was ready, she'd slip through a reconforming doorway concealed behind dense foliage. That way she could appear and disappear in the homeland of the Crakers without raising awkward questions in their minds. (OC: 363)

Crake's whole manipulative activity shows multiple camouflage aspects. On a first level he operates a precautionary concealment; indeed, he keeps his new progeny's existence secret, because the Crakers are the prototype of a project which will lead to the creation of the perfect baby:

They'd be able to create totally chosen babies that would incorporate any feature, physical or mental or spiritual, that the buyer might wish to select. The present methods on offer were very hit-or-miss, said Crake [...] The customers never knew whether they'd get exactly what they'd paid for [...]. (OC: 357$)$

In such a society dominated by biotechnological advances, identity is no longer transmitted or inherited, but is programmed and built in the most literal sense.

At a second stage, the improvement and empowerment of the species is obtained through the hybridization of human with animal matter: "Paradice had already developed a UV-resistant skin, a built-in insect repellent, an unprecedented ability to digest unrefined plant material. As for immunity from microbes, what had until now 
been done with drugs would soon be innate" (OC: 358). But the control over the generation of entire species is only an aspect of Crake's ambitious projects, because another consistent aspect of lifestyle alteration is the administration of a powerful drug, the BlyssPluss, destined to become "a huge money-spinner" (OC: 348). This super-pill promises some attractive benefits, such as a durable youth, protection against sexually transmitted diseases, and, what most counts, an "unlimited supply of libido and sexual prowess" (OC: 346). This miraculous dietary supplement, however, conceals a serious side effect, which is not illustrated in the patient information leaflet: "The BlyssPluss would also act as a sure-fire one-time-does-it- all birth-control pill, for male and female alike, thus automatically lowering the population level" (OC: 347). The cost in terms of human lives of this attempt at sterilizing "people without them knowing" (OC: 347), will be very high, because it will lead to the break out of a pandemic which has the extreme consequence of mankind's decimation. In this desperate and desolated apocalyptical dimension, Snowman is "the ultimate outcast" (Rao, 2006:108) whose struggle for survival also involves the protection and salvation of Crake's offspring, after his friend kills Oryx and is killed in turn by Jimmy. In his melancholic evocation of the past and his hazardous explorative expeditions, Jimmy shows an "increasingly suicidal despair" (Jennings, 2010: 16).

\section{Predators and preys}

On the contrary, Toby and Ren's "investment in the hope for their own survival is the determining factor in their later actions or choices" (Jennings, 2010: 17). In a sequence of de-humanizing events (essential haircuts, accidental sterility and sexual assaults by her boss Blanco), Toby finds in her escape to the God's Gardeners community the possibility of changing her wretched life condition, but this will imply new camouflage and mimic phases. Once among the Gardeners, she makes every effort to adapt to their lifestyle. She becomes one of them embracing their "environmental stewardship, sustainable living practices, and reverence for the interconnectedness of all living things" (Osborne, 2010: 32). It is difficult to distinguish between mimicry and camouflage in this case, because Toby's adaptation process involves her at various levels. She regains, for instance, a 'social status' among the Gardeners by becoming an Eve, a leading position in the 'green community', at the service of other members' needs for medical remedies, as she is expert in botany. Adam One convinces her to accept her task, pointing out the importance of actions over faith: "In [our religion], action precedes faith. You've been acting as if you believe, dear Toby. 'As if' - those two words are very important to us. Continue to live according to them, and belief will follow in time" (YF: 201). Toby accepts her Eve charisma. During her whole existence she has been acting 'as if' for a long-lasting period: 'as if' she was dead, 'as if' she was an inert material to manipulate, 'as if' she was somebody else, 'as if' she was a nobody. But just when she has recovered an interior balance, Blanco's escape from the Painballer causes the necessity for another mimetic, and this time ultimate, remedy: 
plastic surgery. After murdering a woman, Blanco had been confined in the Painballer, a detention camp where prisoners who refused to be executed for their crimes tried to survive attacks from other prisoners. It was very difficult to stay alive, however, because of the harsh custodial conditions:

You got enough food for two weeks, plus the Painball gun - it shot paint, like a regular paintball gun, but a hit in the eyes would blind you, and if you got the paint on your skin you'd start to corrode, and then you'd be an easy target for the throat-slitters on the other team. $(Y F: 117)$

After his escape from the Painballer, Blanco attacks Toby's community and recognizes her. So, in order to safeguard the other Gardeners' security, she decides to undergo an operation which will modify her physical features: "They didn't do much cutting and stitching. Her fingertips lost their sensitivity and her throat was sore from the voicework, and her head itched a lot while the Mo'Hair scalp was bonding. The skin pigmentation was uneven at first" $(Y F, \mathrm{p} .311)$. Once more a process of rearrangement, redefinition, reshaping of her body, treated as inert matter, with unexpected results: "She looked at herself - her new skin, her new abundant hair, her more prominent cheekbones. Her new almond-shaped green eyes" (YF: 312). A complete mimicry, to hide from her main predator (Blanco), to regain a social status, and primarily "to make her more invisible" (YF: 313).

In her new life Toby, now known as Tobiatha, becomes a spa manager with all the individual, social and economic privileges which an identity can guarantee. Her return into society also marks the end of the animalization process to which she had been submitted when she worked for Blanco. Her job at the food chain SecretBurgers represents one of the most demeaning experiences in her life. Blanco was mentally insane, bossy and abusive, with a disagreeable appearance: "He'd kept the signature bouncer ponytail at the back of his balding head, and he sported a full set of arm tattoos: snakes twining his arms, bracelets of skulls around his wrists, veins and arteries on the backs of his hands so they looked flayed" (YF: 43). He addressed his employees with obscene and coarse language and assaulted them sexually. Women were stripped of their humanity, and relegated to the position of mere instrument of self-pleasure. As Plumwood notices, "those on the lower side [...] are obliged to put aside their own interests for those of the master or centre, that they are conceived of as his instruments, a means to his ends. They are made part of a network of purposes which are defined in terms of or harnessed to the master's purposes and needs" (Plumwood, 1993: 53). In this novel the relationship between female objectification and meat consumption is very close. Once out of the SecretBurgers context, Toby becomes a vegetarian, because God Gardeners preached respect and compassion for all living species. But as a worker for the fast food chain, she expressed her perplexities about the origin of the burger meat: "no one knew what sort of animal protein was actually in them" (YF: 40). The recovery of some unconvincing remains in the burgers makes the situation even more alarming, because of the presence of mice tails, human fingernails and occasionally abandoned and unknown corpses. The "meat grinders" (YF: 40) issue raises a series of binary 
interconnected associations: meat/animal, animal/victim, animal/woman, meat/woman, consumerism/exploitation. As Carol J. Adams points out, "inequality is clearly a part of our relationships with the other animals, otherwise we could not experiment upon them, display, hunt, kill and eat them" (Adams, 2003: 18). Furthermore, from an ecocritical perspective, females' inferior status is historically linked to "androcentrism (malecentered thinking)" (Warren, 1997a: 22) and is legitimated by "[a]nimalizing or naturalizing women in a (patriarchal) culture where animals are seen as inferior to humans (men)" (Warren, 1997b: 12).

The obscure origin of the SecretBurgers meat, and the activity of the grinder which destroys any subjective feature and homogenizes the matter into a shapeless mass, recalls, once again, the function of the 'absent referent', which serves "to keep our 'meat' separated from any idea that she or he was once an animal who was butchered" (Adams, 2003: 23). Meat consumption presupposes an absence, which represents the death of the animal substituted by the chunk of meat. Adams suggests a formula for the absent referent: "nonhuman animal + butchering = 'meat'/ consumable flesh/ mass term" (Adams, 2003: 23). As she notices, the process of butchery transforms animals into 'absent referents' because they become absent as animals in the corporeal dimension, in order to let meat exist. On the one hand, their lives precede and permit meat existence. On the other hand, the dead body replaces the living animal, and when its corpse is evoked through language, before the consumers eat it, its presence becomes absence.

The cycle of objectification, fragmentation and sexual exploitation, which sees Toby as the victim of Blanco's perversions, generates her animalization. This concept refers to an "indistinct zone of the inhuman where life is rendered brute" (Seshadri, 2012: 23). Toby has lost her body property, and becomes a non-human being, an object for sexual satisfaction, an assemblage of functional parts. As Eric C. Otto remarks in Green Speculations. Science Fiction and Transformative Environmentalism (2012), "to objectify women makes them available for consumption" (Otto, 2012: 111), which is the completion of oppression and the annihilation of self wish.

\section{Denaturalizing humans and animals}

In Oryx and Crake and in The Year of the Flood the reader faces the disanimalization of the animal body and the animalization of the human body. Both processes develop in terms of the relationship between prey and predator.

In Oryx and Crake we can discuss a "disanimalizing treatment" (De Fontenay, 2012: 13) of the animal matter. The organic material is dismantled, rearranged and reassembled, to create new empowered crossbreeds, with a consequent "denaturing of animality, the production of figures of animality that are so new that they appear monstrous enough to call for a change of name" (De Fontenay, 2012: 13). Atwood fulfils this necessity by creating an appropriate vocabulary which replays on the linguistic level the laboratory species hybridization, as seen above. However, the 
genetically modified creatures soon escape human control, and from the condition of prey of an unlimited thirst for knowledge, shift to the condition of men predators, as in the case of the pigoons, which seem to possess very developed rational abilities, as Jimmy/Snowman points out: "They have something in mind, all right. It's as if they've had it planned [...] They'll be able to lever [the electronic lock] open, pry with their trotters or snouts. They were always escape artists, the pigoons: if they'd had fingers they'd have ruled the world" (OC: 313-14).

In The Year of the Flood animalization, the process "of rendering a living creature into something indistinct, neither human nor animal, namely a brute, is founded on power's ability to manipulate the indeterminacy that haunts all identity" (Seshadri, 2012: 25). In his speech titled "Predator Day", Adam One explains the reason for a celebration which may sound quite contradictory for the Gardeners' life philosophy:

Long ago, we celebrated Predator Day: [...] Our Children would don their faux-fur Predator ears and tails, and at sunset we'd light candles inside the Lions and Tigers and Bears fashioned from perforated tin cans, and the burning-bright eyes of these Predator images would sparkle upon our Predator Day feast. (YF: 413)

As Richard Schechner points out, rituals "arise or are devised around, and to regulate, disruptive, turbulent, dangerous, and ambivalent interactions" (Schechner, 2013: 65). In this case, the celebration of the important role of Predators, which, as living beings, must be respected, has the counterpart of the Outdoor Classroom Predator-Prey demonstration, taught by Zeb, one of the Adams of the Gardeners community. Despite their vegetarian education, which instilled a feeling of "lovingkindness and kinship" (YF: 15) towards the animals, children are also instructed with survival strategies, which imply mimicry and camouflage, as emerges from the Predator-Prey rules: "Seeing without being seen [...] Hearing without being heard. Smelling without being smelled. Eating without being eaten [...] Injuring without being injured" (YF: 165). These strategies are of no use for Toby and Ren during their animal disguises.

One of Toby's first jobs in the realm of anonymity is the 'furzooter': she wears "fake-fur animal suits with cartoon heads", and works at "the higher-end malls and the boutique retail streets" (YF:38) with advertising signs hanging round her neck. The costume is very uncomfortable, and her limited ability to move makes her a victim of the harassments of groups of fetishists, who, during their attacks "rubbed their pelvises against her fur, making strange noises, of which the meows were the most recognizable" (YF: 38). She is profoundly disturbed by this attack with its sexual connotation: "It wasn't rape - no part of her actual body was touched - but it was creepy" (YF: 38). Later on in the narration, she returns to this job, but this time the animal disguise has the aim to keep her identity secret, and to hide her from Blanco, until the operation which will change her physical features forever. This animal stage, however, proves particularly hard for her, as she feels restless, worried and insecure about her possibility of survival: "What if the Gardeners abandoned her and she was left 
to eddy around [...] transformed into a non-existent bird-animal and dehydrating herself to death" $(Y F: 311)$.

Camouflage is the essential aspect of Ren's job as a dancer in Scales and Tails, a sex club for selected costumers, where young girls perform acrobatics in provocative feather or scaly costumes. In this case, her choice to exploit her body for economic advantage is free only from an apparent perspective, because she has become a sex slave, subject to the perversions of Scales' clients, who sometimes commit thoughtless acts. Her job exposes her to some dangerous situations, such as the bite by a passionate admirer during a show. Her condition of prey becomes more intelligible for her when, together with her best friend Amanda, she is captured by some criminals and sexually abused.

The condition of prey, of victim, of vulnerability, makes it inevitable for the protagonists to come up against "the impulse towards violence and vengeance in themselves and others" (Jennings, 2010: 17). In the final part of the novel, Toby, as a predator, faces the controversial feeling of vengeance. She meets Blanco, her torturer, in a desolated gatehouse, lying on the floor, his leg injured. His temperament has not been mitigated by the harsh conditions of his detention: "Turn that fucking thing off! [...] Asshole skinny bitch!" (YF: 456-57). Toby realizes that she is responsible for the rifle bullet in his leg, after the shooting preceding Ren's rescue. He was part of the commando trio who had kidnapped and tortured Ren and Amanda. Her sangfroid in the administration of the poisonous drink to Blanco does not show rage or resentment. Her bad conscience emerges in the words of Zeb. "Don't kid yourself, babe, [...] You had vengeance in mind" $(Y F: 459)$.

\section{Conclusion}

Mimicry and camouflage are two interconnected strategies for survival in Atwood's later post-apocalyptical novels. They presuppose a high level of invisibility, because the first rule to escape from a predator is "Seeing without being seen" (YF: 165). On the performative level, the protagonists of Oryx and Crake and The Year of the Flood face a fragmentation of their self. As a matter of fact, the more they wear their re-created selves shoes, the more they lose themselves. The performed self is "a product of a scene that comes off, and is not a cause to it" (Goffman, 1969: 245) and creates a distance from "its possessor, from the person who will profit or lose most by it, for he and his body merely provide the peg on which something [...] will be hung for a time" (Goffman, 1969: 245). In this process, the corporeal dimension devoid of the human component, and the assimilation between the female and the animal body, generate two distinct consequences: on the one hand, according to the ecocritical perspective, "the inferiorisation of human qualities and aspects of life associated with necessity, nature and women - of nature-as-body, of nature-as-passion or emotion, of nature as the presymbolic, of nature-as primitive, of nature-as-animal and of nature as the feminine continues to operate to the disadvantage of women, nature and the quality of human 
life" (Plumwood, 1993: 21). On the other hand, the instrumental function of the body, which is mutilated, manipulated and camouflaged, relegating it to the condition of mere organic assemblage.

\section{Notes}

1. In the quotations from the texts object of this analysis, the title of Oryx and Crake and The Year of the Flood will be abbreviated respectively as follows: $O C, Y F$.

\section{References}

Atwood, Margaret (1972): Survival. A Thematic Guide to Canadian Literature. Toronto: Anansi. (1972): Survival. London: Virago. (1985): The Handmaid's Tale. London: Virago. (2003): Oryx and Crake. London: Virago.

(2009): The Year of the Flood. London: Virago.

Adams, Carol J. (2003): The Pornography of Meat. Continuum: New York.

Anca Farca Paula (2010): "Margaret Atwood's The Year of the Flood and the Garden of Limited Choices." Margaret Atwood Studies 3(2): 18-21.

Anker, Susan and Doroty Nelkin (eds.) (2004): The Molecular Gaze: Art in the Genetic Age. New York: Cold Spring Harbor Laboratory Press.

Bhabha, Homi K. (1994): The Location of Culture. London and New York: Routledge.

Carlson, Marvin (1996): Performance: A Critical Introduction. London and New York: Routledge.

Cavalieri, Paola (2008): "A Missed Opportunity. Humanism, Anti-humanism and the Animal Question." In J. Castricano, ed., Animal Subjects. An Ethical Reader in a Posthuman World. Waterloo: Wilfred Laurier UP: 97-123.

De Fontenay, Élisabeth (2012) [2008]: Without Offending Humans. A Critique of Animal Rights. Minneapolis: Minnesota U.P.

Goffman, Erving (1969): The Presentation of Self in Everyday Life. London: Penguin.

Haraway, Donna (1991): Simians, Cyborgs, and Women: The Reinvention of Nature. New York: Routledge.

Howells, Coral Ann (2006): "Margaret Atwood's Dystopian Visions: The Handmaid's Tale and Oryx and Crake." In C. A. Howells, ed., The Cambridge Companion to Margaret Atwood. Cambridge: Cambridge University Press: 161-175.

Irigaray, Luce (1985): This Sex That is not One. Ithaca: Cornell University Press.

Jennings, Hope (2010): "The Comic Apocalypse in The Year of the Flood." Margaret Atwood Studies 3(2): 11-18.

Macpherson Slettedhal, Heidi (2010): The Cambridge Introduction to Margaret Atwood. Cambridge: Cambridge University Press.

Osborne, Carol (2010): "Compassion, Imagination, and Reverence for all Living Things: Margaret Atwood's Spiritual Vision in The Year of the Flood." Margaret Atwood Studies 3(2): 30-42. 
Otto, Eric C. (2012): Green Speculations. Science Fiction and Transformative Environmentalism. Columbus: The Ohio State University Press.

Peters, Ted (2002): Playing God: Genetic Determinism and Human Freedom. London: Routledge.

Plumwood, Val (1993): Feminism and the Mastery of Nature. London and New York: Routledge.

Rao, Eleonora (2006) "Home and Nation in Margaret Atwood's Later Fiction." In C. A. Howells, ed., The Cambridge Companion to Margaret Atwood. Cambridge: Cambridge University Press: 100-113.

Seshadri, Kalpana R. (2012): Humanimal. Race, Law, Language. Minneapolis: Minnesota U.P.

Schechner, Richard (2013, third edition): Performance Studies: An Introduction. London and New York: Routledge.

Somacarrera, Pilar (2006): "Power Politics: Power and Identity." In C. A. Howells, ed., The Cambridge Companion to Margaret Atwood. Cambridge: Cambridge University Press: 43-57.

Spivack, Charlotte (ed.) (1992): Merlin versus Faust: Contending Archetypes in Western Culture. London: Edwin Mellen Press.

Staines, David (2006): "Margaret Atwood in her Canadian Context." In C. A. Howells, ed., The Cambridge Companion to Margaret Atwood. Cambridge: Cambridge University Press: 12-27.

Warren, Karen (1997a): Ecofeminist Philosophy: A Western Perspective on What it Is and Why it Matters. Bloomington: Indiana University Press.

(1997b): Ecofeminism: Women, Culture, Nature. Bloomington: Indiana University Press.

Whitford, Margaret (1991). Luce Irigaray. Philosophy in the Feminine. London and New York: Routledge. 